\title{
The Relationship Between State-owned Enterprises Organizational Change and Employees Organizational Commitment ---- An empirical Analysis of taking personality traits and organizational support as intermediate variables
}

\author{
Junzhu Pan \\ Business College, Sichuan University, Yihuan Road, Chengdu, China
}

Keywords: organizational change, personality trait, perceived organization support, organizational commitment

\begin{abstract}
In China, state-owned enterprises belong to special but extremely important types of enterprises. With the constantly changing in political environment, social environment and economic environment, etc., state-owned enterprises are facing a series of organizational changes in recent years. The research on organizational commitment of state-owned enterprise employees with different personality traits under the influence of perceived organization support has practical guiding significance for the important management work of state-owned enterprises in employing, retaining, encouraging and attracting employees, etc.
\end{abstract}

\section{Background and hypothetical models}

The author is studying large state-owned listed companies. With the introduction of new management concepts and models, companies are beginning to start organizational changes in facing the broad environment of change. The organizational commitment of employees has a great impact on the results of organizational change. And different personality traits of employees affect their reaction and cognition to the outside world. The perceived organization support reflects the degree of organizational support perceived by employees in the process of change. The author believes that these two key factors act as intermediate variables before organizational change and organizational commitment, and establish the following research model:

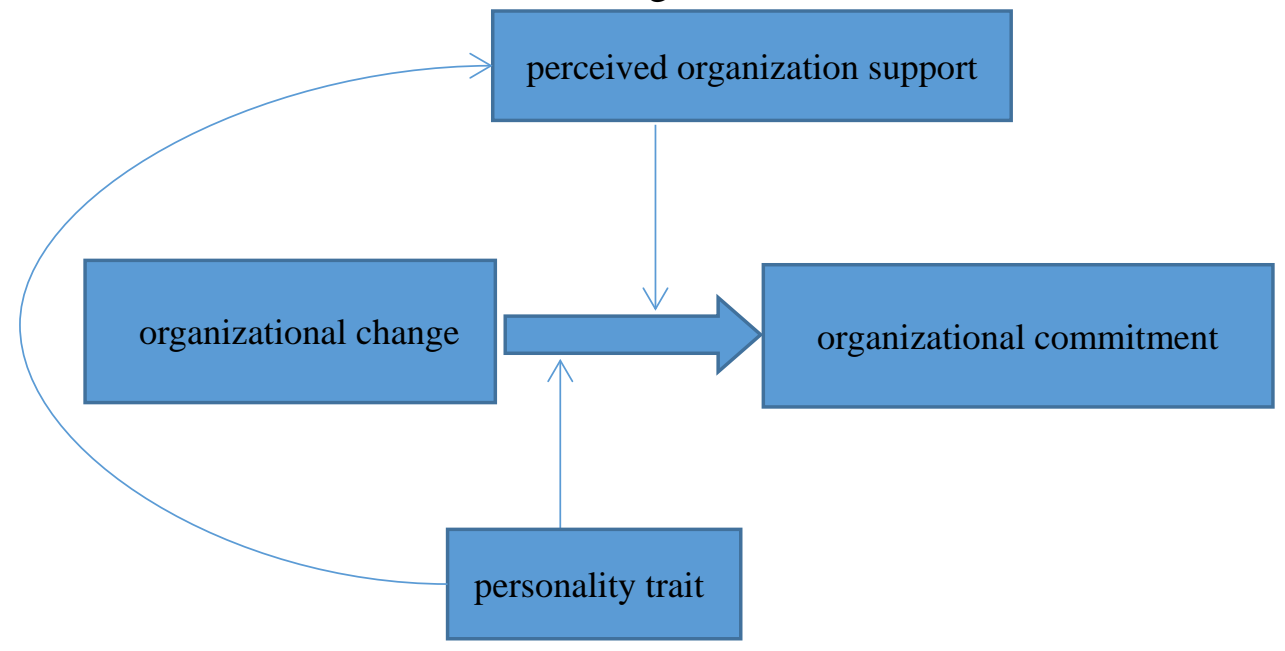

Fig 1. Presumptive model

\section{Review of the theoretical basis}

Organizational change: organizational change is to harmonize organizational functions, interpersonal relationships and role relationships, human abilities and work efficiency by changing and updating the organization in the process of development. 
Personality traits: this paper chooses the "Big-five" trait of Big five Personality Theory, that is, nervousness, extroversion, empirical openness, agreeableness, and responsibility consciousness. This model is generally accepted in academic circles.

Perceived organization support: perceived organization support is a comprehensive perception of whether employees care, respect and support the company. This paper explores the perceived organization support from four aspects: emotional support, tool support, superior support and peer support, respectively.

Organizational commitment: Among many studies, the one proposed by Meyer\&Allen (1991) that the organizational commitment is constituted three aspects, emotional commitment, continuing commitment and normative commitment is the most generally accepted.

\section{Research hypothesis}

\subsection{The relationship between organizational change and organizational commitment}

When the organizational environment begins to change, there is a lot of uncertainty about the changes for employees, and employees have different perceptions of the threats and challenges brought by the changes, so the following assumptions are put forward: H1 The organizational change has a negative impact on organizational commitment. H1a The organizational change has a negative effect on emotional commitment. H1b The organizational change has a negative impact on continued commitment. H1c The organizational change has a negative impact on normative commitments.

\subsection{The relationship between organizational change and organizational commitment for employees with different personality traits}

Personality traits play a key role in the cognition and reaction of individuals to the outside world. Based on the characteristics of different dimensions of personality traits, the following assumptions are made: H2a The relationship between organizational change and organizational commitment of neurotic employees is negative. H2b The relationship between the organizational change of extroverted employees and their organizational commitment is negative. H2c The relationship between organizational change and organizational commitment of empirical openness employees is irrelevant. H2d The relationship between organizational change and organizational commitment of agreeableness employees is positive. H2e The relationship between organizational change and organizational commitment of responsibility consciousness employees is irrelevant.

\subsection{The sense of organization support is the concern and identity of the organization perceived by employees in the process of reform.}

The stronger employees' feelings are, the higher their dependence and identity to the organization will be. According to the characteristics of different dimensions of organizational support and organizational commitment, the following hypothesis is made: H3 The organizational support has a positive influence on organizational commitment. H3a The emotional support has a positive effect on organizational commitment.H3b The tool support has a positive impact on organizational commitment. H3c The superior support has a positive effect on organizational commitment. H3d The colleagues' support had a positive effect on organizational commitment. H3e The sense of organizational support is a significant adjustment between organizational change and organizational commitment.

\subsection{The relationship between personality traits and organizational support}

Different personality traits have different perceived levels of organizational support, so the following hypothesis is made:H4a The neuroticism was positively correlated with organizational support. H4b The extraversion was positively correlated with perceived organizational support. H4c The openness to experience is positively correlated with organizational support. H4d The humaneness is positively related to the sense of organizational support. H4e The responsibility consciousness has no correlation with the sense of organization support. 


\section{Questionnaire design}

According to the organizational change situation of the research object, the author designed 7 questions. The "big five" personality questionnaire was modified by Haward in 1996. Based on exploratory research on domestic employees conducted by Lling Wenquan (2000) and others, seven questions on emotional support, four questions on tool support, one question on superior support and one question on subordinate support were designed for background samples of state-owned enterprises in this study, and the sense of organizational support was explored. According to the general application, the organizational commitment questionnaire extracts three questions about emotional commitment, three questions about continuous commitment, three questions about normative commitment, from the three-factor scale developed by Allen and Meyer.

\section{Sample information}

The objects of this research are employees of large state-owned enterprises. A total of 358 questionnaires were randomly distributed, and 358 questionnaires were collected, all of which are valid. The effective rate of recovery is $100 \%$. Of which, the proportion of men and women are $55.9 \%$ and $44.1 \%$, respectively. The age group "under 22 " is $10.3 \%$, the age group of $23-28$ is $26.3 \%$, the age group of $29-34$ is $31.6 \%$, the age group of $35-40$ is $15.1 \%$, the age group of above 41 is $16.8 \%$, "senior high school and below" education is $17.6 \%$, junior college is $43 \%$, "undergraduate" is $33.8 \%$, postgraduate is $5.3 \%$, and doctor is $0.3 \%$.

\section{Empirical analysis results}

\subsection{Reliability analysis}

This research test scale are used Richter five-point scale, a score of 5 represents a very consistent, and a score of 1 represents a very inconsistent, the reliability is Cronbach's $\alpha$ as a measurement index. It is generally believed that the value of Cronbach's $\alpha$ is at least greater than 0.70 , the Cronbach's $\alpha$ of the organizational change scale is 0.798, the Cronbach's $\alpha$ of the Big-five Personality trait scale is 0.706 , the Cronbach's $\alpha$ of the organizational support scale is 0.960 and the Cronbach's $\alpha$ of the organizational commitment scale is 0.844 . The reliability of the questionnaire is good.

\subsection{Research results}

\subsubsection{The relationship between organizational change and organizational commitment}

Table 1 The correlation between organizational change and organizational commitment

\begin{tabular}{|c|c|c|c|c|c|c|}
\hline & & $\begin{array}{c}\text { Degree of } \\
\text { organizational } \\
\text { change }\end{array}$ & $\begin{array}{c}\text { Emotional } \\
\text { commitment }\end{array}$ & $\begin{array}{c}\text { Continual } \\
\text { commitment }\end{array}$ & $\begin{array}{c}\text { Norm } \\
\text { commitment }\end{array}$ & $\begin{array}{c}\text { Organizational } \\
\text { commitment }\end{array}$ \\
\hline \multirow{2}{*}{$\begin{array}{c}\text { Degree of } \\
\text { organizational } \\
\text { change }\end{array}$} & Pearson correlation & 1 & $-.233^{* *}$ & $.121^{*}$ & $-.153^{* *}$ & $-.107^{*}$ \\
\hline & Significant (bilateral) & & .000 & .022 & .004 & .044 \\
\hline
\end{tabular}

**. Significant correlation at. 01 level (bilateral).

*. Significant correlation at level 0.05 (bilateral). 


\subsubsection{The relationship between organizational change and organizational commitment for different personality traits}

1) Nervousness

Table 2 The correlation between organizational change and organizational commitment for individual neuroticism

\begin{tabular}{|r|r|r|}
\hline & $\begin{array}{c}\text { Degree of organizational } \\
\text { change }\end{array}$ & $\begin{array}{c}\text { organizational } \\
\text { commitment }\end{array}$ \\
\hline Degree of organizational change $\quad$ Pearson correlation & 1 & -.120 \\
& Significant (bilateral) & \\
$\mathrm{N}$ & 440 \\
& 44 \\
\hline
\end{tabular}

\section{2) Extroversion}

Table 3 The correlation between organizational change and organizational commitment for individual extroversion

\begin{tabular}{|c|c|c|c|}
\hline & & $\begin{array}{c}\text { Degree of organizational } \\
\text { change }\end{array}$ & Organizational commitment \\
\hline \multirow[t]{2}{*}{ Degree of organizational change } & $\begin{array}{l}\text { Pearson correlation } \\
\text { Significant (bilateral) }\end{array}$ & 1 & $\begin{array}{r}-.204^{* *} \\
.007\end{array}$ \\
\hline & $\mathrm{N}$ & 172 & 172 \\
\hline
\end{tabular}

**. Significant correlation at. 01 level (bilateral).

3) Empirical openness

Table 4 The correlation between organizational change and organizational commitment for individual empirical openness

\begin{tabular}{|cr|r|r|}
\hline & & Degree of organizational change & Organizational commitment \\
\hline \multirow{2}{*}{$\begin{array}{c}\text { Degree of organizational } \\
\text { change }\end{array}$} & Pearson correlation \\
& Significant (bilateral) & 1 & -.154 \\
$\mathrm{~N}$ & & .378 \\
& & 35 & 35 \\
\hline
\end{tabular}

\section{4) Agreeableness}

Table 5 The correlation between organizational change and organizational commitment for individual agreeableness

\begin{tabular}{|c|c|c|c|}
\hline & & Degree of organizational change & $\begin{array}{c}\text { Organizational } \\
\text { commitment }\end{array}$ \\
\hline \multirow[t]{2}{*}{ Degree of organizational change } & $\begin{array}{l}\text { Pearson correlation } \\
\text { Significant (bilateral) }\end{array}$ & 1 & $\begin{array}{r}-.227^{* *} \\
.000\end{array}$ \\
\hline & $\mathrm{N}$ & 260 & 260 \\
\hline
\end{tabular}

**. Significant correlation at. 01 level (bilateral). 
5) Responsibility consciousness

Table 6 The correlation between organizational change and organizational commitment for individual responsibility consciousness

\begin{tabular}{|rr|r|r|}
\hline & & Degree of organizational change & Organizational commitment \\
\hline Degree of organizational change & Pearson correlation & 1 & $-.222^{* *}$ \\
& Significant (bilateral) & & .000 \\
$\mathrm{~N}$ & & 276 & 276 \\
\hline
\end{tabular}

**. Significant correlation at. 01 level (bilateral).

\subsubsection{The role of perceived organization support in organizational change and organizational commitment}

1) Descriptive analysis results

On the whole of the sample, the perceived organization support reaches 4, and organizational commitment reaches 3.3, which reflects a typical characteristic of state-owned enterprises. That is, the welfare of state-owned enterprises is good, the resources enjoyed by employees are relatively rich, and the organizational support work is well carried out. However, the organizational commitment of employees is only a general level, which does not match with the high level of organizational support, and also a manifestation of the general lack of vitality of employees in state-owned enterprises.

Table 7 Descriptive statistics on organizational support and organizational commitment

\begin{tabular}{|l|r|r|r|}
\hline & Mean value & $\begin{array}{r}\text { Standard } \\
\text { deviation }\end{array}$ & \multicolumn{1}{|c|}{$\mathrm{N}$} \\
\hline perceived organization support & 3.9854 & .93769 & 358 \\
Organizational commitment & 3.3116 & .82661 & 358 \\
Emotional support & 3.8667 & .95818 & 358 \\
Tool support & 3.8904 & 1.03172 & 358 \\
Superior support & 4.0503 & 1.11909 & 358 \\
Peer support & 4.1341 & 1.04461 & 358 \\
\hline
\end{tabular}

2) Correlation analysis

However, in contrast to the above study, tool support and emotional support were found to be more influential than superior support and peer support.

Table 8 The correlation between perceived organization support and organizational commitment

\begin{tabular}{|c|c|c|c|c|c|c|c|}
\hline & & $\begin{array}{c}\text { Perceived } \\
\text { organization support }\end{array}$ & $\begin{array}{c}\text { Organizational } \\
\text { commitment }\end{array}$ & $\begin{array}{c}\text { Emotional } \\
\text { support }\end{array}$ & $\begin{array}{c}\text { Tool } \\
\text { support }\end{array}$ & $\begin{array}{l}\text { Superior } \\
\text { support }\end{array}$ & $\begin{array}{c}\text { Peer } \\
\text { support }\end{array}$ \\
\hline \multirow{3}{*}{$\begin{array}{c}\text { Organizational } \\
\text { commitment }\end{array}$} & Pearson correlation & $.650^{* *}$ & 1 & $.624^{* *}$ & $.658^{* *}$ & $.559^{* *}$ & $.514^{* *}$ \\
\hline & $\begin{array}{c}\text { Significant } \\
\text { (bilateral) }\end{array}$ & .000 & & .000 & .000 & .000 & .000 \\
\hline & $\mathrm{N}$ & 358 & 358 & 358 & 358 & 358 & 358 \\
\hline
\end{tabular}

**. Significant correlation at. 01 level (bilateral).

3) Regression analysis

Regression analysis of organizational change and organizational commitment: 
Table 9 Regression Analysis coefficient of organizational change and organizational commitment $^{2}$

\begin{tabular}{|c|c|c|c|c|c|}
\hline \multirow[b]{2}{*}{ Model } & \multicolumn{2}{|c|}{ Non-standardized coefficient } & \multirow{2}{*}{$\begin{array}{c}\text { Standard coefficient } \\
\text { Trial version }\end{array}$} & \multirow[b]{2}{*}{$\mathrm{t}$} & \multirow[b]{2}{*}{ Sig. } \\
\hline & $\mathrm{B}$ & Standard error & & & \\
\hline 1 (Constant) & 3.571 & .135 & & 26.402 & .000 \\
\hline Degree of organizational change & -.100 & .049 & -.107 & -2.026 & .044 \\
\hline
\end{tabular}

a. Dependent variable: organizational commitment

There is a negative relationship between organizational change and organizational commitment, and $\mathrm{R} 2=0.011$, that is, the degree of organizational change can explain $1.1 \%$ of organizational commitment. Therefore, the degree of organizational change is not the key factor to affect organizational commitment.

Table 10 Summary on regression analysis model of organizational change and organizational commitment

\begin{tabular}{|c|c|c|c|c|c|c|c|c|c|}
\hline \multirow[b]{2}{*}{ Model } & \multirow[b]{2}{*}{$\mathrm{R}$} & \multirow[b]{2}{*}{$\mathrm{R}$ side } & \multirow[b]{2}{*}{$\begin{array}{c}\text { Adjusting } \\
\text { R side }\end{array}$} & \multirow{2}{*}{$\begin{array}{l}\text { Standard } \\
\text { estimation } \\
\text { error }\end{array}$} & \multicolumn{5}{|c|}{ Change statistics } \\
\hline & & & & & $\begin{array}{l}\mathrm{R} \text { side } \\
\text { change }\end{array}$ & F change & df1 & df2 & $\begin{array}{l}\text { Sig. F } \\
\text { change }\end{array}$ \\
\hline 1 & $.107^{\mathrm{a}}$ & .011 & .009 & .82303 & .011 & 4.105 & 1 & 356 & .044 \\
\hline
\end{tabular}

a. Predictive variables: (constant), degree of organizational change.

Regression analysis of organizational change, perceived organization support and organizational commitment:

Table 11 Regression analysis coefficient of organizational change, perceived organization support and organizational commitment ${ }^{2}$

\begin{tabular}{|c|c|c|c|c|c|c|}
\hline \multirow{2}{*}{\multicolumn{2}{|c|}{ Model }} & \multicolumn{2}{|c|}{ Non-standardized coefficient } & \multirow{2}{*}{$\begin{array}{c}\text { Standard coefficient } \\
\text { Trial version }\end{array}$} & \multirow[b]{2}{*}{$\mathrm{t}$} & \multirow[b]{2}{*}{ Sig. } \\
\hline & & B & Standard error & & & \\
\hline \multirow[t]{3}{*}{1} & (Constant) & .697 & .205 & & 3.396 & .001 \\
\hline & Degree of organizational change & .089 & .039 & .095 & 2.268 & .024 \\
\hline & Perceived organization support & .598 & .037 & .678 & 16.178 & .000 \\
\hline
\end{tabular}

a. Dependent variable: organizational commitment

In multiple regression analysis, the degree of organizational change and perceived organization support are positively correlated with organizational commitment. The $\mathrm{R} 2=43.1 \%$, that is, the degree of organizational change and perceived organization support, together explain $43.1 \%$ of organizational commitment. Compared with the regression analysis of organizational change and organizational commitment in Table 9, the standard coefficient is -0.107 . When variables are added to the perceived organization support, the standard coefficient of organizational change and organizational commitment is 0.095 , which shows that organizational support has a very important impact on organizational commitment, and acts as a moderating variable in organizational change and organizational commitment. 
Table 12 Summary on regression analysis model of organizational reform, perceived organization support and organizational commitment

\begin{tabular}{|c|c|c|c|c|c|c|c|c|c|}
\hline \multirow[b]{2}{*}{ Model } & \multirow[b]{2}{*}{$\mathrm{R}$} & \multirow[b]{2}{*}{$\mathrm{R}$ side } & \multirow[b]{2}{*}{$\begin{array}{c}\text { Adjusting } \\
\text { R side }\end{array}$} & \multirow{2}{*}{$\begin{array}{l}\text { Standard } \\
\text { estimation } \\
\text { error }\end{array}$} & \multicolumn{5}{|c|}{ Change statistics } \\
\hline & & & & & $\begin{array}{l}\mathrm{R} \text { side } \\
\text { change }\end{array}$ & F change & df1 & df2 & $\begin{array}{c}\text { Sig. F } \\
\text { change }\end{array}$ \\
\hline 1 & $.656^{\mathrm{a}}$ & .431 & .428 & .62531 & .431 & 134.421 & 2 & 355 & .000 \\
\hline
\end{tabular}

a. predictive variable: (constant), perceived organization support, degree of organizational change.

\subsubsection{The relationship between personality traits and organizational support}

Table 13 The correlation between personality traits and organizational support

\begin{tabular}{|c|c|c|c|c|c|c|c|}
\hline & & $\begin{array}{c}\text { Perceived } \\
\text { organization } \\
\text { support }\end{array}$ & Nervousness & Extraversion & $\begin{array}{l}\text { Empirical } \\
\text { openness }\end{array}$ & Agreeableness & $\begin{array}{l}\text { Responsibility } \\
\text { consciousness }\end{array}$ \\
\hline $\begin{array}{c}\text { Perceived } \\
\text { organization } \\
\text { support }\end{array}$ & $\begin{array}{c}\text { Pearson } \\
\text { correlation } \\
\text { Significant } \\
\text { (bilateral) }\end{array}$ & 更 & $\begin{array}{l}.405^{* *} \\
.000\end{array}$ & $\begin{array}{l}.067 \\
.203\end{array}$ & $\begin{array}{l}.321^{* *} \\
.000\end{array}$ & $\begin{array}{r}-.157^{* *} \\
.003\end{array}$ & $\begin{array}{r}-.246^{* *} \\
.000\end{array}$ \\
\hline & $\mathrm{N}$ & 358 & 358 & 358 & 358 & 358 & 358 \\
\hline
\end{tabular}

**. Significant correlation at. 01 level (bilateral).

*. Significant correlation at level 0.05 (bilateral).

\section{Summary of research results and suggestions for management measures}

1) H1 that 'The organizational change has a negative impact on organizational commitment.'is correct. Therefore, the organization should carry out employee communication activities or reform policy publicity activities before the start of the reform, which will increase the participation of employees and solicit their opinions widely to improve their understanding and trust of the change. It is better to develop supporting incentives for employees to establish a sense of ownership so as to maintain or improve their organizational commitment, which will lay the foundation for the success of the organizational change.

2) H1a that 'The organizational change has a negative impact on emotional commitment.'is correct. Emotional commitment decreases when employees complain about "constant change" and mistrust of change.

3) H1b that 'The organizational change has a negative impact on the continuous commitment.'is wrong,the impact is positive . The benefits and stability of state-owned enterprises are good, and the employees pay special attention to the existing benefits or status, or try to maintain them. Therefore, as long as the appropriate are prepared for the changes and increase the participation of employees, with effective supporting policies, these changes can be helpful for improving the organizational commitment of employees. Especially in the state-owned background companies,t with relatively weak vitality environment, the changes can bring the motivation of continuous progress.

4) H1c that 'The organizational change has negative influence on normative commitment.'is correct. For some employees, the organizational change breaks the original agreement and needs to rebuild the psychological contract between them and the enterprise. 
5) H2a that 'The relationship between employee organizational change and organizational commitment for neurotic employees is negative.'is wrong and the correlation is not significant. Therefore, the organizational change has little influence on the organizational commitment of neurotic employees or as long as they are good at emotional experience.

6) H2b that 'The relationship between organizational change and organizational commitment of extraverted employees is negative.'is correct. This kind of employees should be encouraged to take an active and confident attitude to participate in the change,the organization need to communicate and feedback to them, and give them the opportunity to launch employee activities, so as to improve their enthusiasm and help the change to proceed smoothly.

7) H2c that 'The relationship between organizational change and organizational commitment of experience openness employees is not related.'is correct. Management measures for this part of employees should focus on stimulating their curiosity and letting them use their imagination and creativity to plan to how to help the organizational change to achieve success, which is of great help to improve their organizational commitment.

8) H2d that ' The relationship between organizational change and organizational commitment of agreeableness employees is positive.'is wrong,the relationship is significantly negative. The management of these employees should create an atmosphere of mutual help and common progress, and guide them to believe that the organizational change is to make everyone better, which requires their joint efforts to achieve the common development of the enterprise and employees.

9) H2e that 'The relationship between organizational change and organizational commitment for responsibility consciousness employees is not relevant.'is wrong, the relationship is significantly negative. The management of these employees should be mainly based on the consensus of setting goals and providing conditions for them to achieve the goals.

10) H3 that 'The perceived organizational support has a positive influence on organizational commitment.' is correct.H3a that 'The emotional support has a positive influence on organizational commitment.'is correct.H3b that 'The tool support has a positive influence on organizational commitment.'is correct. H3c that 'The superior support has a positive influence on organizational commitment.'is correct. H3d that 'The colleagues support has a positive influence on organizational commitment.'is correct.The perceived organizational support acts as an important variable between organizational change and organizational commitment. $\mathrm{H} 4 \mathrm{a}$ that 'The relationship between neuroticism and perceived organizational support is positive.'is wrong,the relationship is significantly negative.H4b that 'The relationship between extraversion and perceived organizational support is positive.'is wrong,it is not relevant. H4c that 'The relationship between empirical openness and perceived organizational support is positive.'is wrong, the relationship is significantly negative. H4d that 'The relationship between agreeableness and perceived organizational support is positive.'is correct.H4e that ' responsibility consciousness and perceived organizational support is not relevant.' is wrong,it is significantly positive.

In this series of conclusions, you can see that the support of the organization has a big impact on the employee organization, and it can't be ignored in the process of organizational change.And employees who have different personality traits, and the sense of organization support is different, the more neurotic and the more experienced open the employees are, the lower they feel about the organizational support. Employees who are more tend to be agreeableness and responsibility consciousness,they have higher sense the feel about the organizational support, the organization needs to make a specific and effective management decision.

\section{References}

[1] Allport F H,Allport G.W.Personality Traits:Their Classification and Measurement[J].Journal of Abnormal and Psychology,1921,16,1-40

[2] Li Hongyan. Introduction to "big five" personality factor model [J]. Journal of Shaanxi Normal University (Philosophy and social sciences edition), 2002,S1:89-91

[3] Li Jingjing. Introduction to "big five" personality model and application [J]. Journal of Luoyang 
Normal University, 2006,(02)

[4] Liu Yufan, Wang Er'ping. The relationship between Big five personality and job performance [J]. Psychological trends,2000,(3):73-80.

[5] Zhang Jun, Wu Song. An empirical study on the relationship between organizational support and organizational commitment[J].Western Economic Management Forum, 2013,(02)

[6] Chen Shuang. A study on the impact of organizational change to organizational commitment[J]. Academic exchanges, 2011,(12)

[7] Bilal Afsar,Yuosre Badir,Muhammad Muddassar Khan. Person-job fit,person-organization $\mathrm{f}$ it and innovative work behavior:The mediating role of innovation trust[J]. Journal of High Technology Management Research.2015 (26 ) :105-116.

[8] Hollen,R. M . A . ,Van den Bosch ,F. A . J. ,\&V olberda,H . The role of management innovation in enabling technological process innovation:And inter0rganizati0nal perspective[J].European Management Review.2013.10:35-50. 